\title{
Peran Kecerdasan Sosial terhadap Resiliensi pada Mahasiswa Tingkat Awal
}

\author{
Annisa Andriani, Ratih Arruum Listiyandini \\ Universitas YARSI, Jl. Letjend Suprapto Kav. 13 Jakarta Pusat \\ e-mail: annisa.andriani2@gmail.com
}

\begin{abstract}
First-year university students experienced various demands and problems, such as developmental tasks, role transition processes, academic's demands, and anxieties. To be more resilient when facing those demands and problems, increasing quality and quantity of social connection are needed; therefore, they need social intelligence. This research examined the role of social intelligence on resilience. 177 college freshmen in Jakarta were chosen with incidental sampling technique. This study used adaptation of Tromso Social Intelligence Scale to measure social intelligence and adaptation of Connor Davidson - Resilience Indicator Scale to measure resilience. Simple regression analysis shows that social intelligence contributes in about $16 \%$ on resilience. Multiple regression analysis shows that social information processing has the most significant role among other dimensions of social intelligence. This dimension describes the ability to understanding various (social) messages in social environment. Thus, social intelligence development is imperative for enhancing the resilience of first year students in the university.
\end{abstract}

Keywords: college freshmen, resilience, social intelligence

\begin{abstract}
Abstrak
Mahasiswa tingkat awal menghadapi berbagai tuntutan dan masalah, diantaranya tuntutan tugas perkembangan, proses transisi peran, tuntutan akademik, dan kecemasan. Untuk dapat menjadi lebih resilien dalam menghadapi tuntutan dan permasalahan tersebut, perlu adanya peningkatan kualitas dan kuantitas hubungan sosial, dimana hal ini membutuhkan adanya kecerdasan sosial. Penelitian ini bertujuan untuk mengetahui bagaimana peran kecerdasan sosial terhadap resiliensi. 177 orang mahasiswa tingkat awal di Jakarta dipilih menggunakan teknik incidental sampling. Penelitian ini menggunakan adaptasi skala Tromso Social Intelligence Scale untuk mengukur kecerdasan sosial dan adaptasi skala Connor Davidson - Resilience Indicator Scale untuk mengukur resiliensi. Hasil uji regresi sederhana menunjukkan bahwa kecerdasan sosial memiliki kontribusi terhadap resiliensi sebesar 16\%. Berdasarkan hasil uji regresi ganda, ditemukan bahwa dimensi pengolahan informasi sosial memiliki kontribusi paling signifikan. Dimensi ini menggambarkan kemampuan individu memahami pesan-pesan di lingkungannya. Sehingga, perlu adanya pengembangan kecerdasan sosial sebagai upaya dalam peningkatan resiliensi mahasiswa tingkat awal di perguruan tinggi.
\end{abstract}

Kata Kunci: mahasiswa tingkat awal, resiliensi, kecerdasan sosial

\section{Pendahuluan}

Masa-masa awal perkuliahan adalah sebuah masa dimana remaja mengalami transisi peran dari siswa menjadi seorang mahasiswa. Sebagai mahasiswa, remaja harus menghadapi berbagai norma sosial dan akademik yang berbeda dengan norma sosial dan akademik yang berlaku saat mereka masih duduk di bangku sekolah menengah (Shields, 2002; Dickie dan Farrell, 1991 dalam Karp, 2007). Sebagai contoh, seorang mahasiswa harus memiliki rasa tanggung jawab yang lebih besar daripada siswa sekolah menengah dan seorang mahasiswa sudah harus bisa menentukan prioritasnya sendiri, perihal manajemen waktu, dan lainnya (www.smu.edu, diakses pada 16 Oktober 2015). 
Clark (2005) menyatakan bahwa kesuksesan seorang mahasiswa tingkat awal dilihat dari keberhasilannya menjalani masa transisi. Proses transisi peran ini dipengaruhi oleh beberapa hal. Diantaranya adalah pengalaman mereka ketika memasuki perguruan tinggi, seperti interaksi yang terjadi antara individu dengan dosen, staf, dan teman-teman sebayanya. Selain itu, hubungan yang mereka jalani dengan orang lain di luar lingkungan perguruan tingginya, seperti orangtua, teman sebaya, dan organisasi di luar kampus juga berperan dalam proses transisi peran ini (Tinto, 1993; Weidman, 1989; dalam Clark, 2005).

Rata-rata usia seseorang masuk kuliah adalah 18 hingga 19 tahun. Sesuai dengan teori mengenai tugas perkembangan psikososial Erikson, pada tahap ini individu akan menjalani proses pencarian identitas diri. Proses pencarian identitas diri inilah yang mengarahkan seorang individu untuk membangun interaksi yang lebih banyak dengan orang lain di sekitarnya (Sokol, 2009). Sehubungan dengan hal ini, para spesialis di bidang kesehatan mental menyatakan bahwa gangguan mental seperti depresi seringkali terjadi pada masamasa awal perkuliahan ini. Salah satunya disebabkan oleh kecemasan akan proses membangun hubungan baru dengan orang asing (Liebert, 2003; Gately, 2005 dalam Hernandez, 2007).

Munculnya tanggung jawab-tanggung jawab baru juga menjadi salah satu dari lima faktor utama penyumbang stres bagi mahasiswa (Ross, Niebling, dan Heckert, 1999). Tanggung jawab baru ini contohnya seperti tanggung jawab untuk dapat menghidupi diri sendiri, dapat melakukan segala sesuatu secara mandiri, untuk menjalani perkuliahan dengan baik, dan lain-lain, dapat menjadi faktor penyebab stres tersendiri bagi mahasiswa tingkat awal. Oleh karena itu, agar mahasiswa mampu berhasil dalam menjalani pendidikannya, mahasiswa tersebut harus mampu menyesuaikan diri dengan lingku- ngannya yang baru (Rosiana, 2011). Beberapa aspek yang dapat memengaruhi proses penyesuaian diri ini adalah kemasyarakatan, social confidence, hubungan dengan dosen, dan hubungan dengan teman sebaya (Strage dan Brandt, 1999; Prasetyawati, 2003 dalam Rosiana, 2011).

Segala tuntutan penyesuaian sosial ini dapat menjadi stresor bagi mahasiswa tingkat awal (Sgan-Cohen dan Lowental, 1988 dalam Ross dkk., 1999). Stresor yang tidak teratasi, akan berdampak pada kesehatan mental mahasiswa. Seperti halnya yang dikemukakan oleh Verger, Combes, Kovess-Masfety, Choquet, Guagliardo, Rouillon, dan Peretti-Wattel (2009) bahwa tingkat distress psikologis pada mahasiswa cenderung lebih tinggi dibandingkan dengan populasi pekerja dengan jenis kelamin dan usia yang sama. Tingkat distress psikologis yang tinggi berkaitan dengan perasaan cemas dan depresi, harga diri yang rendah, dan juga kemampuan yang rendah dalam berkonsentrasi, mengatasi kesulitan, dan terlibat dalam hubungan sosial (Goldberg dan Williams, dalam Listiyandini dan Akmal, 2015). Stres psikologis tersebut juga dapat menghambat kemampuan belajar dan memberi atensi (Ursin dan Eriksen, 2004, 2010), yang pada akhirnya dapat mengganggu performa akademik mahasiswa (Dyrbye, Thomas, dan Shanafelt, dalam Listiyandini dan Akmal, 2015).

Oleh karena itu, untuk dapat tetap berfungsi secara normal di tengah berbagai macam faktor penyebab stres, mahasiswa membutuhkan suatu kemampuan untuk beradaptasi dengan masalah, termasuk dengan faktor-faktor penyebab stres itu. Kemampuan individu untuk dapat beradaptasi dengan masalah, bertahan, mengatasi, dan berkembang di tengah kesulitan inilah yang disebut dengan resiliensi (Connor dan Davidson, 2003). Connor dan Davidson (2003) menyatakan bahwa resiliensi dapat juga dipandang 
sebagai pengukuran mengenai kemampuan coping stress yang dianggap sukses. Orang yang resilien memiliki beberapa karakteristik personal, seperti memiliki regulasi emosi yang baik, daya tahan terhadap stress, fleksibel dan mampu menerima perubahan, memiliki hubungan yang lekat dengan orang lain, dan memiliki kontrol diri (Reivich dan Shatte, 2002; Connor dan Davidson, 2003). Dengan karakteristik yang dimilikinya, orang yang resilien memiliki kapasitas untuk berrespon secara sehat dan produktif dalam menghadapi kesulitan (Reivich dan Shatte, 2002). Oleh karena itu, dengan memiliki resiliensi, mahasiswa tingkat awal diharapkan akan lebih mampu untuk bangkit kembali dari masalah yang dihadapi dalam penyesuaian diri di perguruan tinggi, menghadapi faktor-faktor penyebab stres, sehingga terhindar dari berbagai masalah kesehatan mental.

Terkait dengan gambaran resiliensi mahasiswa, penelitian yang dilakukan oleh Hutapea (2006) menemukan bahwa mayoritas mahasiswa tingkat pertama yang merantau hanya memiliki tingkat resiliensi yang tergolong sedang. Begitu pula dengan penelitian yang dilakukan oleh Amelia, Asni, dan Chairilsyah (2014), ditemukan bahwa $89,07 \%$ mahasiswa tahun pertama memiliki tingkat resiliensi yang tergolong sedang. Hal ini disebabkan karena sulitnya membangun komunikasi dengan lingkungan baru dan permasalahan akademik. Data tersebut mengindikasikan bahwa pengembangan resiliensi bagi mahasiswa tingkat awal masih sangat diperlukan.

Untuk itu, demi mendukung peningkatan resiliensi pada mahasiswa tingkat awal, diperlukan pengetahuan mengenai faktor-faktor yang dapat mendukung resiliensi itu sendiri. Penelitian terdahulu menunjukkan bahwa resiliensi bisa dipengaruhi oleh adanya faktor protektif internal di dalam diri individu itu sendiri. Riset di negara Barat menunjukkan faktor protektif yang secara umum dianggap berperan adalah regulasi emosi, pengendalian diri, fleksibilitas kognitif, efikasi diri, optimisme, empati, dan keinginan mencari tantangan baru (Reivich dan Shatte, 2002).

Dalam konteks kehidupan mahasiswa, khususnya pada masa transisi di tingkat awal, mahasiswa tidak hanya membutuhkan kemampuan untuk bisa bangkit dari kesulitan yang dihadapi, namun mengingat adanya stressor yang bersifat sosial, maka mahasiswa tingkat awal juga harus mampu beradaptasi dengan situasi sosial yang baru. Kemampuan adaptasi dalam lingkungan sosial yang baru membutuhkan suatu keterampilan dalam berhubungan baik dengan orang-orang di sekitar. Keterampilan ini disebut sebagai kecerdasan sosial. Kecerdasan sosial adalah kemampuan untuk dapat berhubungan baik dengan orang-orang di sekitar, dan mampu membuat mereka mau bekerja sama dengan kita (Albrecht, 2014). Kecerdasan sosial merupakan salah satu dari kekuatan karakter yang dimiliki individu (Peterson dan Selligman, 2004 dalam Linley dan Joseph, 2004). Sebagai kekuatan karakter, kecerdasan sosial ini penting sebagai kontrol perilaku dalam kehidupan bermasyarakat sehari-hari. Perilaku anarkis pada mahasiswa salah satunya dapat diakibatkan oleh kecerdasan sosial yang rendah (www.uad.ac.id)

Penelitian terhadap subjek mahasiswa secara umum di Universitas $Y$ menunjukkan bahwa kekuatan karakter kecerdasan sosial berkorelasi secara signifikan dengan resiliensi pada mahasiswa (Listyandini dan Akmal, 2015). Hasil ini sejalan dengan teori bahwa salah satu karakter yang dimiliki individu yang resilien adalah memiliki hubungan dekat dengan orang lain (Connor dan Davidson, 2003). Sebagai mahasiswa tingkat awal yang memiliki berbagai tuntutan akan peningkatan hubungan sosial, seorang mahasiswa membutuhkan kecerdasan sosial yang baik agar ia mampu mengatasi segala tuntutan-tuntutan yang muncul dan dapat 
berkembang di dalamnya. Untuk mengatasi tuntutan akademik, mahasiswa tersebut harus mampu menyesuaikan diri dengan lingkungan perkuliahannya (Rosiana, 2011). Proses penyesuaian diri ini dipengaruhi oleh bagaimana mahasiswa tersebut dapat membangun hubungan yang baik dengan dosen dan teman-teman sebayanya (Strage dan Brandt, 1999; Prasetyawati, 2003 dalam Rosiana, 2011). Dengan kata lain, untuk dapat menyesuaikan diri dengan lingkungannya secara cepat dan mudah, mahasiswa tersebut membutuhkan kecerdasan sosial yang baik. Dengan memiliki kecerdasan sosial yang baik, individu tersebut akan dapat menjadi resilien dalam menghadapi segala tuntutan dan faktor pemicu stres sebagai mahasiswa tingkat awal. Berdasarkan hal ini, peneliti memprediksi bahwa kecerdasan sosial seharusnya dapat menjadi salah satu faktor yang dapat mempengaruhi resiliensi para mahasiswa tingkat awal.

Adanya peran kecerdasan sosial terhadap resiliensi pada mahasiswa tingkat awal perlu diteliti lebih lanjut. Terlebih lagi, beberapa penelitian seperti yang dilakukan oleh Vancu (2014), baru menemukan bahwa terdapat beberapa kesamaan aspek antara kecerdasan sosial dan kecerdasan emosional. Penelitian dari Friborg, Barlaug, Martinussen, Rosenvinge, dan Hjemdal (2005) juga sekedar menemukan bahwa aspek kompetensi sosial dalam resiliensi berkorelasi positif dengan konstruk keterampilan sosial pada subjek dewasa. Penelitian lainnya mengenai hubungan antara kecerdasan sosial dan resiliensi pada mahasiswa (Listyandini dan Akmal, 2015) juga hanya dilakukan pada populasi mahasiswa secara umum tanpa melihat fenomena spesifik pada mahasiswa tingkat awal. Sebaliknya, peneliti belum menemukan adanya penelitian mengenai peranan kecerdasan sosial terhadap resiliensi pada mahasiswa tingkat awal.
Di sisi lain, dengan mengetahui peran kecerdasan sosial terhadap resiliensi pada mahasiswa tingkat awal, proses pengembangan resiliensi mahasiswa di tahun pertama akan menjadi lebih terarah. Selain itu, penelitian juga menemukan bahwa murid yang memiliki perasaan terhubung dengan sekolah, guru, dan temannya memiliki prestasi akademik yang baik (Libbey, 2004 dalam Bennett, 2015). Ini menunjukkan bahwa murid dengan kecerdasan sosial yang baik akan memiliki prestasi yang baik pula.

Berdasarkan pada data dan fenomena yang ada, maka peneliti tertarik untuk mencari tahu mengenai peranan kecerdasan sosial terhadap resiliensi pada mahasiswa tingkat awal. Untuk penelitian ini, peneliti akan mengambil subjek mahasiswa tingkat awal di Jakarta, yang mana memiliki jumlah mahasiswa baru terbesar di Indonesia dan memiliki perguruan tinggi terbanyak kedua di Indonesia (Kementerian Pendidikan dan Kebudayaan, 2013). Peneliti memiliki hipotesis bahwa kecerdasan sosial berperan positif terhadap resiliensi mahasiswa tingkat awal. Dalam hal ini, kecerdasan sosial yang tinggi dapat diikuti oleh resiliensi yang tinggi pula pada mahasiswa tingkat awal. Begitu pula sebaliknya, kecerdasan sosial yang rendah dapat diikuti oleh resiliensi yang rendah pada mahasiswa tingkat awal.

Dengan meneliti peran kecerdasan sosial terhadap resiliensi, tidak hanya akan bermanfaat pada pengembangan diri mahasiswa itu sendiri, namun juga pada institusi pendidikan tinggi tempat mahasiswa bernaung. Pada mahasiswa tingkat awal, penelitian ini bisa menjadi informasi mengenai urgensi dari kecerdasan sosial dalam rangka pengembangan resiliensi diri. Selain itu, bagi pengambil kebijakan di perguruan tinggi, penelitian ini diharapkan dapat menjadi bahan masukan terkait dengan proses orientasi maupun pengembangan mahasiswa tingkat awal di perguruan tinggi. 


\section{Kecerdasan Sosial}

Silvera, Martinussen, dan Dahl (2001) merumuskan bahwa kecerdasan sosial merupakan kemampuan untuk memahami orang lain dan bagaimana mereka akan berreaksi dalam situasi sosial yang berbeda. Definisi ini didapatkan berdasarkan hasil penelitian kualitatif yang dilakukan oleh Silvera dkk. (2001). Mereka menemukan beberapa karakteristik individu yang dianggap berhubungan dengan konstruk kecerdasan sosial, yaitu: (1) memahami orang lain; (2) memahami konteks sosial; (3) menerima sudut pandang orang lain; dan (4) memprediksi reaksi orang lain.

Dari studi pilot tersebut Silvera dkk. (2001) juga merumuskan bahwa kecerdasan sosial terdiri atas tiga faktor utama, yaitu: (1) Social information processing (SP)/ pengolahan informasi sosial, yang mencakup segala kemampuan untuk memahami pesan verbal maupun nonverbal terkait dengan hubungan antar manusia, berempati dan membaca pesan tersembunyi maupun pesan eksplisit dari orang lain; (2) Social skills (SS)/ keterampilan sosial, yang mengukur keterampilan dasar komunikasi, seperti mendengar aktif, berperilaku secara terus terang, membentuk, mempertahankan, dan mengakhiri sebuah hubungan; dan (3) Social awareness (SA)/ kesadaran sosial, yang mencakup segala kemampuan untuk dapat berperilaku secara aktif sesuai dengan situasi, tempat, dan waktu.

Berdasarkan studi peneliti pada beberapa literatur, peneliti menyimpulkan bahwa terdapat empat faktor yang dapat memengaruhi pembentukan kecerdasan sosial pada seorang individu, termasuk juga pada mahasiswa. Faktor tersebut adalah keluarga, letak geografis, pengalaman berorganisasi, dan sekolah.

Keluarga. Penelitian yang dilakukan oleh Rozali (2015) menemukan bahwa perbedaan penerapan pola asuh dapat memengaruhi kecerdasan sosial seorang anak. Pola asuh autoritatif memberikan pengaruh yang paling besar terhadap perkembangan kecerdasan sosial seorang anak. Hasil penelitian ini juga didukung oleh pernyataan Mangoenprodjo (dalam Rozali, 2015), bahwa salah satu faktor yang memengaruhi pembentukan kecerdasan sosial seorang remaja adalah hubungan orangtua dan anak pada masa perkembangan awal individu tersebut.

Kedekatan Letak Geografis antara Tempat Tinggal Asal dan Tempat Kuliah. Frankovsky dan Birknerova (2014) menyatakan bahwa terdapat beberapa faktor yang dapat memengaruhi kecerdasan sosial yang dimiliki oleh seseorang, salah satunya adalah kedekatan letak geografis. Teori ini didukung dengan hasil penelitian yang dilakukan oleh Soejanto dan Soekarman (2015), yang meneliti tentang tingkat kecerdasan sosial mahasiswa pada Universitas Kanjuruhan Malang. Hasil penelitian menunjukkan bahwa mahasiswa yang berasal dari Pulau Jawa memiliki persentase kecerdasan sosial dengan tingkat tinggi yang lebih besar daripada mahasiswa lain yang berasal dari luar Jawa. Jika dihubungkan dengan fenomena yang ada dalam kehidupan mahasiswa, dapat disimpulkan bahwa kecerdasan sosial mahasiswa rantau akan berbeda dengan kecerdasan sosial mahasiswa yang berdomisili dan berkuliah di daerah yang sama.

Pengalaman Berorganisasi. Organisasi merupakan suatu kelompok yang terdiri dari beberapa orang, yang saling berinteraksi dan memengaruhi untuk mencapai suatu tujuan yang telah ditetapkan bersama (Umbara, Lilik, dan Agustin, 2012). Individu yang memiliki pengalaman organisasi akan memiliki kesempatan yang lebih besar untuk dapat berinteraksi dengan orang lain. Intensitas berinteraksi ini dapat membantu individu tersebut dalam mengembangkan keterampilan sosialnya. Keterampilan sosial ini merupakan salah satu dimensi dari kecerdasan sosial (Silvera dkk., 2001). Kemudian, sejalan dengan usaha masingmasing anggota organisasi untuk mencapai tujuan yang telah mereka tetapkan bersama, 
individu dengan pengalaman organisasi akan dapat mengembangkan sikap manajemen diri, membangun kemampuan untuk dapat berhubungan baik dengan pihak di dalam maupun di luar organisasi, dan sikap terbuka terhadap masukan (Umbara dkk., 2012). Jika dikaitkan dengan pembahasan sebelumnya, kemampuankemampuan tersebut juga termasuk ke dalam keterampilan sosial seseorang. Oleh karena itu, pengalaman organisasi yang dimiliki individu dapat memengaruhi pembentukan kecerdasan sosial pada diri individu tersebut.

Sekolah. Sistem maupun teknik pembelajaran di sekolah dapat memengaruhi perkembangan kecerdasan sosial individu. Teknik pembelajaran yang menonjolkan proses kelompok dapat lebih meningkatkan perkembangan kecerdasan sosial individu, daripada teknik pembelajaran individual. Ini sesuai dengan hasil penelitian Wicaksono dan Naqiyah (2013) bahwa teknik bermain peran dalam bimbingan kelompok dapat meningkatkan kemampuan komunikasi interpersonal subjek. Komunikasi interpersonal subjek inilah yang akan membantu subjek dalam memahami kejadian-kejadian di sekelilingnya, serta untuk menguji kesankesan dan pengertiannya tentang dunia sekitar (Supratiknya, 2000 dalam Wicaksono dan Naqiyah, 2013). Dengan kata lain, dapat membantu subjek dalam memahami konteks sosial di lingkungan sekitarnya. Kemampuan individu dalam memahami konteks sosialnya ini, termasuk karakteristik individu dengan kecerdasan sosial. Oleh karena itu, peneliti berkesimpulan bahwa teknik pembelajaran yang diterapkan di sekolah dapat memengaruhi pengembangan kecerdasan sosial seorang individu. Jika sistem pembelajaran secara kelompok ini diterapkan sejak usia dini, maka kemungkinan besar hal tersebut dapat memengaruhi pembentukan kecerdasan sosial seorang anak.

\section{Resiliensi}

Menurut Connor dan Davidson (2003), resiliensi merupakan suatu kualitas personal yang memungkinkan seseorang untuk dapat berkembang di tengah kesulitan yang dihadapinya. Resiliensi juga dapat dilihat sebagai ukuran kemampuan seseorang dalam mengatasi stress, dimana hal ini dapat menjadi target untuk penyembuhan kecemasan, depresi, dan reaksi stress (Connor dan Davidson, 2003). Jadi, dapat disimpulkan bahwa resiliensi adalah suatu kualitas personal berupa kemampuan seseorang untuk mengatasi stress, yang memungkinkan orang tersebut untuk bisa berkembang di tengah kesulitan yang dihadapinya.

Menurut Connor dan Davidson (2003), resiliensi seorang individu dibentuk oleh lima faktor, yaitu;

Kompetensi personal, standar yang tinggi, dan kegigihan. Seseorang yang resilien akan selalu memberikan usaha terbaiknya untuk mendapatkan tujuannya. Ia juga tidak akan mudah putus asa, tidak mudah menyerah dalam proses mendapatkan tujuannya. Orang yang resilien juga memandang positif tantangan yang ada di hadapannya, bukan sebagai sesuatu yang menakutkan melainkan sebagai suatu tantangan yang patut diambil. Dengan demikian, orang tersebut akan mampu mengatasi dan berkembang di tengah masalah yang dihadapinya.

Keyakinan terhadap insting, toleransi terhadap efek negatif, dan efek menguatkan dari stress. Orang yang resilien tidak akan ragu mengambil keputusan sesuai dengan instingnya, walaupun keputusan tersebut bukan keputusan yang populer ataupun sulit. Ia juga akan mampu menoleransi efek-efek negatif dari stress ataupun masalah yang sedang dihadapinya, seperti perasaan yang tidak nyaman, kelelahan pikiran, dan lainlain dengan caranya sendiri. Sejalan dengan ini, untuk mendukung usahanya dalam menoleransi efek negatif itu, ia akan melihat sisi humoris dari masalah tersebut, 
bukan hanya sisi negatifnya. Jadi, orang tersebut akan membentuk pola pikir yang positif terhadap stress atau masalah, bahwa stress dan masalah tersebut adalah sumber kekuatan untuk berkembang menjadi lebih baik lagi, bukan sebagai hal yang menurunkan kemampuan dirinya.

Penerimaan positif terhadap
perubahan dan hubungan lekat dengan
orang lain. Orang yang resilien tidak kaku
dalam menghadapi perubahan maupun masalah yang datang. Ia akan menyesuaikan dirinya sedemikian rupa sehingga apapun hal yang terjadi, tidak menurunkan performanya. Orang yang resilien juga cenderung memiliki hubungan yang lekat dan aman dengan orang lain, yang menjaganya agar tetap dapat berfungsi dengan baik di tengah masalah yang sedang dihadapinya, seperti dengan teman dekat, orangtua, ataupun pasangannya.

Kontrol. Orang yang resilien memiliki kontrol akan dirinya sendiri. Ia tahu apa yang harus ia lakukan, ia mengenal tujuannya dengan baik, dan ia akan tahu ke mana harus meminta pertolongan ketika menghadapi suatu masalah.

Pengaruh spiritual. Percaya akan kuasa Tuhan dan bahwa segala sesuatu terjadi karena suatu alasan, juga merupakan salah satu dari faktor yang membentuk resiliensi pada individu.

Connor dan Davidson (2003) dalam penelitiannya, juga menyimpulkan bahwa terdapat beberapa karakteristik yang menandakan individu yang resilien, yaitu: (1) melihat perubahan atau stress sebagai sebuah tantangan atau kesempatan; (2) memiliki komitmen; (3) memiliki rekognisi akan batasan diri sebagai kontrol diri; (4) memiliki dukungan orang lain; (5) memiliki hubungan yang dekat dan aman dengan orang lain; (6) memiliki tujuan pribadi dan kolektif; (7) memiliki kepercayaan diri; (8) memanfaatkan efek menguatkan dari stress; (9) (mengambil hikmah dari) kesuksesan di masa lalu (untuk menyelesaikan masalah); (10) perasaan yang realistik akan kontrol/ ketika memiliki pilihan; (11) memiliki rasa humor; (12) menggunakan pendekatan yang berorientasi pada tindakan; (13) memiliki kesabaran; (14) memiliki toleransi akan pengaruh negatif; (15) dapat menyesuaikan diri terhadap perubahan; (16) memiliki optimisme; dan (17) memiliki keyakinan.

Penelitian dalam 20 tahun terakhir mengenai resiliensi telah menghasilkan rumusan bahwa resiliensi merupakan karakteristik multidimensional dari individu, yang bervariasi sesuai konteks, waktu, usia, gender, dan pengaruh kultural. Secara lebih lengkapnya, resiliensi individu dipengaruhi oleh beberapa faktor (Fan, Pandya-Lorch, dan Yosef, 2014; Widuri, 2012; Bhana dan Bachoo, 2011; Rinaldi, 2010; Brougham, Zail, Mendoza, dan Miller, 2009; Landau, 2007; Everall, Altrows, dan Paulson, 2006; Sonn dan Fisher, 1998). Faktor-faktor ini dapat dikelompokkan menjadi dua kelompok besar, yaitu;

\section{Faktor Internal}

Kemampuan kognitif. Kemampuan kognitif dapat memengaruhi resiliensi seorang individu dalam hal pemecahan masalahnya. Untuk dapat memecah-kan sebuah masalah, individu butuh adanya proses kognitif, dimana ia akan berusaha mencari solusi terbaik untuk masalahnya, dengan segala pertimbangan yang ada di dalamnya. Asumsi ini didukung oleh hasil penelitian longitudinal yang dilakukan oleh Fergusson dan Lynskey (1996, dalam Everall dkk., 2006) pada remaja sering terpapar dengan kesulitan yang terjadi dalam keluarga selama masa kecilnya. Penelitian tersebut menemukan bahwa ketika berusia delapan tahun, remaja dengan penyesuaian diri yang sehat memiliki IQ yang lebih tinggi daripada IQ yang dimiliki remaja dengan masalah penyesuaian diri. Namun, Levine (2002, dalam Everall dkk., 2006) menyatakan bahwa kecerdasan yang dimaksud dapat meningkatkan resiliensi bukan hanya 
sekedar kecerdasan berdasarkan skor IQ saja. Kecer-dasan yang dimaksud dalam hal ini termasuk pula kemampuan untuk memahami orang lain maupun diri sendiri pada konteks situasi yang lebih luas. Seperti, bagaimana harus bersikap di depan orang yang lebih tua, bagaimana cara berkomunikasi pada orang yang sama namun pada konteks peran yang berbeda, dan lain-lain.

Gender. Ketika mendapatkan sebuah masa-lah, perempuan dan laki-laki memiliki perbedaan dalam proses mengatasi stressnya. Umumnya, perempuan cenderung lebih sering menggunakan emotion focused coping daripada laki-laki (Brougham dkk., 2009), yaitu dengan lebih menekankan pada penanggulangan dampak emosional yang muncul. Namun, berdasarkan penelitian yang dilakukan oleh Brougham dkk. (2009), ternyata penggunaan emotion focused coping mahasiswa laki-laki menjadi lebih tinggi ketika menghadapi stres yang berkaitan dengan keluarga. Dari penelitian itu pula didapatkan bahwa secara umum penggunaan emotion focused coping lebih tinggi daripada penggunaan problem focused coping pada subjek mahasiswa (Brougham dkk., 2009). Perempuan dan laki-laki juga memiliki kemampuan yang berbeda dalam mengelola dan bertahan di tengah krisis. Laki-laki dianggap lebih mampu dalam bertahan di tengah krisis daripada perempuan, karena perempuan lebih sulit mengelola dan mendapatkan akses menuju sumber daya tertentu, yang berguna untuk membantunya menyelesaikan krisis yang dihadapi (Kumar dalam Fan dkk., 2014).

Keterikatan individu dengan budaya. Individu yang berasal dari etnis minoritas yang 'terpisah', akan lebih menjaga kohesivitas kelom-poknya dan sengaja membuat identitas baru yang terpisah dari kelompok etnis mayoritas. Identitas baru itu termasuk di dalamnya strategi-strategi mengenai bagai-mana harus bertahan di tengah etnis mayoritas, dan itu membuat indi-vidu yang ada di dalam etnis tersebut menjadi lebih resilien terhadap tekanan dari etnis mayoritas (Sonn dan Fisher, 1998).

\section{Faktor Eksternal}

Keluarga. Peran keluarga terhadap resiliensi individu sangat penting. Pengalaman masa kecil seorang individu yang berasal dari keluarganya akan memengaruhi perkembangan resi-liensi individu itu nantinya (Breinbauer dan Maddaleno, 2005 dalam Bhana dan Bachoo, 2011). Greenspan (2002, dalam Bhana dan Bachoo, 2011) menyatakan bahwa resiliensi bukanlah atribut tunggal dari seorang anak, melainkan meru-pakan sebuah produk dari hubungan anak tersebut dengan keluarga ataupun pengasuhnya. Hubungan ini juga harus berjalan sedemikian rupa dan sesuai dengan profil perkem-bangan anak yang unik.

Komunitas. Komunitas dapat menjadi wadah untuk berbagi cerita mengenai pengalaman traumatik individu, seperti bencana alam, terorisme, dan lain-lain. Proses berbagi pengala-man ini dapat membantu generasi selanjutnya atau anggota lain untuk dapat bertahan di tengah trauma yang sama. Resiliensi dalam hal ini diartikan sebagai kemampuan para anggota komunitas untuk dapat menyelesaikan konflik transisional yang telah mampu mereka lewati, serta strategi-strategi pemecahan masalah yang berhasil digunakan selama konflik itu terjadi (Landau, 2007). Jika dikaitkan dengan kehidupan sehari-hari, individu akan menjadi lebih resilien dengan adanya komunitas, karena di dalam komunitas tersebut terdapat individu-individu lain yang memi-liki masalah yang sama. Adanya kesamaan kondisi tersebut, membuat individu yang ber-sangkutan dapat menceritakan masalahnya dan meminta pendapat mengenai strategi untuk mengatasi masalahnya itu. Dengan begitu, individu tersebut dapat belajar dari pengalaman orang lain yang sebelumnya dengan masalah yang sama, memahami peran dirinya dalam situasi saat itu, dan 
memadukan pengetahuan-penge-tahuan yang didapat tersebut untuk menentukan perilakunya di masa depan terkait masalahnya (Landau, 2007).

Tingkat Sosial Ekonomi. Faktor demografi yang meliputi pendapatan memiliki hubungan yang signifikan dengan resiliensi (Barends dalam Rinaldi, 2010). Dalam penelitiannya, Permata (2015) menemukan bahwa berda-sarkan tingkat pengeluarannya, mahasiswa tingkat awal yang memiliki tingkat sosial ekonomi yang tinggi lebih resilien daripada mahasiswa dengan tingkat sosial ekonomi yang lebih rendah.

Asal Universitas. Penelitian yang dilakukan Permata (2015) pada mahasiswa tingkat awal yang merantau menunjukkan bahwa mahasiswa dari universitas negeri memiliki tingkat resiliensi yang lebih tinggi daripada mahasiswa yang berasal dari universitas swasta.

\section{Mahasiswa Tingkat Awal, Kecerdasan Sosial, dan Resiliensi}

Sebagai seorang mahasiswa tingkat awal, seorang individu akan menghadapi berbagai tuntutan, yaitu tuntutan tugas perkembangan, proses transisi peran, dan tuntutan akademik (Sokol, 2009; Liebert, 2003 dan Gately, 2005 dalam Hernandez, 2007; Clark, 2005). Ketiga tuntutan ini, memerlukan penyelesaian yang mengarah pada peningkatan jumlah dan kualitas hubungan sosial, seperti kebutuhan bersosialisasi untuk menemukan identitas diri, kemampuan bergaul untuk dapat menyesuaikan diri dengan situasi baru ketika kuliah dalam rangka menyukseskan proses transisi peran, dan kebutuhan untuk membangun hubungan yang baik dengan dosen dan teman sebaya sebagai usaha untuk membantu pemenuhan tuntutan akademis. Dengan memiliki kecerdasan sosial, mahasiswa tersebut mampu untuk mengatasi berbagai tuntutannya sebagai mahasiswa tingkat awal tersebut. Mahasiswa menjadi mampu untuk mempertahankan performanya pada tahun pertama kuliah tersebut dan dapat berkembang dalam segala tuntutan dan masalah yang dihadapinya. Kemampuan untuk dapat mengatasi dan berkembang dalam masalah inilah yang disebut resiliensi (Connor dan Davidson, 2003). Konstruk resiliensi juga beririsan dengan konstruk kecerdasan sosial dalam hal karakteristik individunya, yaitu kedua konstruk tersebut sama-sama menunjukkan adanya peran hubungan sosial dalam karakteristik individunya.

Oleh karena itu, peneliti berhipotesa bahwa kecerdasan sosial memiliki peran terhadap resiliensi yang dimiliki oleh mahasiswa tingkat awal. Ketika seorang mahasiswa tingkat awal memiliki kecerdasan sosial yang baik, maka ia akan lebih mampu bertahan dan mengatasi segala tuntutan dan faktor pemicu stress di sekelilingnya yang menuntut peningkatan kualitas dan kuantitas hubungan sosial. Sebaliknya, mahasiswa tingkat awal dengan kecerdasan sosial yang lebih rendah akan lebih sulit untuk dapat bertahan dan mengatasi segala tuntutan dan faktor pemicu stress di sekelilingnya. Dengan begitu, kecerdasan sosial yang dimiliki oleh seorang mahasiswa tingkat awal dapat memprediksi resiliensinya terhadap segala tuntutan dan masalah yang ia hadapi pada tahun pertama perkuliahannya.

\section{Metode Penelitian}

\section{Rancangan/ Desain Penelitian}

Penelitian ini menggunakan pendekatan kuantitatif dengan dua variabel yaitu variabel bebas (independent variable) dan variabel terikat (dependent variable). Desain penelitian ini adalah penelitian asosiatif, dimana peneliti ingin mengetahui hubungan dari kedua variabel penelitian. Penelitian asosiatif adalah salah satu desain penelitian yang bertujuan untuk mengetahui hubungan antara dua variabel penelitian atau lebih (Sugiyono, 2010). Dalam hal ini, konstruk yang diteliti adalah konstruk kecerdasan sosial dan resiliensi. Untuk menguji hipotesis pada penelitian ini, 
peneliti menggunakan teknik regresi sederhana dan ganda, karena peneliti ingin meramalkan bagaimana perubahan/ naik turunnya variabel terikat, jika variabel bebas sebagai prediktornya dimanipulasi (dinaik-turunkan). Variabel bebas/ prediktor (X) pada penelitian ini adalah kecerdasan sosial dan variabel terikat/ kriterianya (Y) adalah resiliensi.

\section{Populasi dan Sampel Penelitian}

Populasi dalam penelitian ini adalah mahasiswa tingkat awal yaitu mereka yang sedang berada pada tahun pertama perkuliahan di perguruan tinggi yang ada di DKI Jakarta. Peneliti mengambil sampel di DKI Jakarta, karena berdasarkan hasil perhitungan statistik terakhir pada tahun ajaran 2012/ 2013, DKI Jakarta adalah provinsi dengan jumlah mahasiswa baru terbanyak di Indonesia. Berdasarkan data statistik terakhir pada tahun ajaran 2012/2013, jumlah mahasiswa baru di Jakarta mencapai 226.974 orang. DKI Jakarta juga memiliki jumlah universitas terbanyak kedua di Indonesia, setelah Jawa Timur (Kementerian Pendidikan dan Kebudayaan 2013).

Dalam penelitian ini, peneliti menentukan karakteristik dari sampel penelitian. Karakteristik sampelnya yaitu;

Mahasiswa tingkat awal, yang sedang berada pada tahun pertama kuliah. Peneliti mengambil sampel ini, karena karakteristik mahasiswa tingkat awal yang sedang berada pada tahun pertama kuliah berkaitan dengan latar belakang konstruk kecerdasan sosial dan resiliensi yang akan diambil peneliti, seperti yang telah dijelaskan pada bab sebelumnya.

Berusia 17-19 tahun, dengan jenis kelamin baik perempuan maupun laki-laki. Peneliti memilih sampel maha-siswa baru berusia 17-19 tahun, karena biasanya individu memasuki jenjang perkuliahan pada usia 18-19 tahun (Kementerian Pendidikan dan Kebudayaan 2013). Peneliti juga mengambil sampel dengan jenis kelamin perempuan dan laki-laki, karena peneliti ingin melihat korelasi antara kedua variabel pada subjek secara umum tanpa membedakan laki-laki atau perempuan.

Berasal dari universitas di daerah DKI Jakarta. Untuk pengambilan sampel, peneliti menggunakan teknik nonprobability sampling. Teknik nonprobability sampling merupakan "teknik pengambilan sampel yang tidak memberi peluang atau kesempatan bagi setiap unsur atau anggota populasi untuk dipilih menjadi sampel" (Sugiyono, 2012).

Berdasarkan pertimbangan bahwa peneliti akan mengambil sampel hanya berdasarkan kriteria-kriteria yang cukup umum, maka peneliti memutuskan untuk menggunakan teknik incidental sampling. Incidental sampling merupakan salah satu teknik sampling yang prosesi penentuan sampelnya dilakukan secara kebetulan (Sugiyono, 2010). Orang-orang yang secara kebetulan (incidental) bertemu dengan peneliti dan memiliki karakteristik yang sesuai dengan karakteristik sampel penelitian, peneliti pilih untuk dijadikan sampel penelitian. Dalam hal ini, peneliti memperoleh subjek penelitian mahasiswa tingkat awal melalui jaringan orang-orang terdekat dan menyebarkan data melalui daring dengan menggunakan fitur di dalam web survey. Kuesioner tersebut disebarkan pada mahasiswa tingkat awal di Jakarta.

Dari proses pengambilan data, jumlah responden pada penelitian ini adalah 177 orang, yang merupakan mahasiswa tingkat awal yang berusia antara 17-19 tahun dan sedang berkuliah di wilayah DKI Jakarta. Peneliti memastikan bahwa setiap responden adalah mahasiswa tingkat awal (semester 1 atau 2) yang sedang berkuliah di daerah DKI Jakarta. Sebagian besar responden penelitian ini adalah mahasiswa tingkat awal yang berusia 18 tahun $(60,5 \%)$, berjenis kelamin perempuan $(71,8 \%)$, bukan mahasiswa rantau $(67,2 \%)$, memiliki pengalaman organisasi $(81,4 \%)$, dan berasal dari universitas swasta $(79,7 \%)$. Ditinjau dari pengeluarannya, mayoritas partisipan memiliki pengeluaran perbulan 
sebesar Rp. 1.000.000,00 - Rp. 2.000.000,00. Kemudian untuk suku bangsanya, mayoritas partisipan lahir dari keturunan ayah dan ibu yang berbeda suku $(33,9 \%)$.

\section{Teknik Pengumpulan Data}

Instrumen penelitian yang digunakan adalah adaptasi skala TSIS (Tromso Social Intelligence Scale) yang disusun oleh Silvera dkk. (2001) untuk mengukur kecerdasan sosial, yang terdiri dari 21 item; dan adaptasi skala CD-RISC (Connor Davidson - Resilience Indicator Scale) yang disusun oleh Connor dan Davidson (2003) untuk mengukur resiliensi partisipan, yang terdiri dari 25 item. Metode pengumpulan data yang dilakukan melalui kedua alat ukur ini adalah metode skala, yaitu skala TSIS (kecerdasan sosial) dan skala CD-RISC (resiliensi). Kedua skala ini menggunakan model skala likert.

\section{Skala Kecerdasan Sosial}

Untuk mendapatkan gambaran mengenai kecerdasan sosial yang dimiliki subjek, peneliti menggunakan skala Tromso Social Intelligence Scale (TSIS). Alat ukur ini dibuat dan disusun oleh Silvera, Martinussen, dan Dahl pada tahun 2001. Skala ini terdiri atas 21 item, dengan 10 item favorable dan 11 item unfavorable. Item-item terbagi berdasarkan tiga faktor/ dimensi yang mendasarinya, yaitu faktor pengolahan informasi sosial, faktor keterampilan sosial, dan faktor kesadaran sosial. Namun, berdasarkan hasil uji validitas ketika try out, hanya 19 item yang valid nilainya. Sehingga, untuk penelitian ini peneliti hanya menggunakan 19 item tersebut. Berikut blueprint dari alat ukur TSIS:

Tabel 1

Blueprint Skala Kecerdasan Sosial

\begin{tabular}{ccc}
\hline $\begin{array}{c}\text { Faktor yang } \\
\text { diukur }\end{array}$ & Item & $\begin{array}{c}\text { Favorablel } \\
\text { Unfavorable }\end{array}$ \\
\hline $\begin{array}{c}\text { Pengolahan } \\
\text { Informasi } \\
\text { Sosial }\end{array}$ & $1,3,6,9,17$, & Favorable \\
Fon & 19 & \\
& &
\end{tabular}

\begin{tabular}{ccc}
$\begin{array}{c}\text { Keterampilan } \\
\text { Sosial }\end{array}$ & $7,10,18$, & $\begin{array}{c}\text { Favorable } \\
\text { Unfavorable }\end{array}$ \\
$\begin{array}{c}\text { Kesadaran } \\
\text { Sosial } \\
\text { Jumlah item }\end{array}$ & $2,5,8,15,20$ & Unfavorable \\
& 13,16 & \\
\hline
\end{tabular}

Skor kecerdasan sosial didapatkan dari hasil pengukuran menggunakan skala Likert dengan 7 alternatif pilihan jawaban berupa angka 1 sampai 7 . Skor 7 untuk pernyataan yang dianggap sangat menggambarkan diri subjek, dan skor 1 untuk pernyataan yang dianggap sangat tidak menggambarkan diri subjek. Alat ukur ini juga terdiri atas dua jenis item, yaitu item favorable dan unfavorable. Skor kecerdasan sosial subjek dapat dilihat dari skor total subjek secara keseluruhan maupun skor total perdimensi/ persubskala pada skala TSIS ini. Untuk skor total secara keseluruhan, semakin tinggi skor total subjek, maka semakin tinggi pula kecerdasan sosial subjek. Begitu pula sebaliknya, semakin rendah skor total subjek, maka semakin rendah pula kecerdasan sosialnya. Sedangkan untuk skor total subjek perdimensi, semakin tinggi skor total subjek pada dimensi/ subskala tersebut, maka semakin tinggi pula kemampuan yang dipersepsikan subjek pada dimensi/ subskala tersebut dan begitu pula sebaliknya.

Skala TSIS pada awalnya merupakan skala berbahasa Norwegia. Namun, untuk proses adaptasi alat ukur ini, peneliti menggunakan versi terjemahan berbahasa Inggris yang dipaparkan oleh Silvera dkk. (2001) dalam jurnal alat ukurnya. Untuk mengadaptasi item pada alat ukur TSIS yang akan peneliti gunakan, peneliti melakukan beberapa kali proses penerjemahan. Setelah melewati proses penerjemahan, peneliti kemudian mempersiapkan item-item terjemahan tersebut untuk uji expert judgement, uji keterbacaan, dan uji validitas serta reliabilitas sebelum dijadikan sebagai item final untuk kuesioner. 
Berdasarkan hasil uji reliabilitas saat proses uji coba, alat ukur TSIS memiliki nilai koefisien reliabilitas yang $>0,6$, baik secara keseluruhan maupun per dimensi. Dengan demikian, dapat disimpulkan bahwa alat ukur TSIS memiliki nilai reliabilitas yang baik dan layak digunakan sebagai instrumen pengambilan data penelitian (Sunjoyo, Carolina, Magdalena, dan Kurniawan, 2013). Berikut tabel kesimpulan uji reliabilitas dari hasil uji coba yang telah peneliti lakukan:

Tabel 2

Hasil Uji Reliabilitas TSIS

\begin{tabular}{cc}
\hline & Hasil Uji \\
\hline Keseluruhan & 0,817 \\
Dimensi Social Information & 0,811 \\
Processing & 0,784 \\
Dimensi Social Skills & 0,770 \\
Dimensi Social Awareness & \\
\hline
\end{tabular}

Kemudian, berdasarkan uji validitas item menggunakan teknik corrected item total correlation, terdapat dua buah item yang tidak valid karena memiliki koefisien validitas yang $<0,2$. Standar sebuah item dianggap valid dan layak digunakan adalah jika memiliki koefisien korelasi pada nilai corrected item total di atas 0,2 (Nisfiannoor, 2009). Berdasarkan hasil corrected item total, item 14 dan 21 harus dibuang karena memiliki koefisien validitas yang negatif.

Secara keseluruhan, nilai koefisien validitas yang didapat pada tahap uji coba memiliki rentang nilai koefisien yang berkisar antara 0,261 - 0,534. Dari hasil tersebut dapat disimpulkan bahwa semua item dalam alat ukur TSIS valid dan layak digunakan untuk mengukur kecerdasan sosial. Berikut tabel kesimpulan dari kedua hasil uji validitas yang telah dilakukan:

Tabel 3

Hasil Uji Validitas TSIS

\begin{tabular}{cc}
\hline & Koef. Validitas \\
\hline Keseluruhan & $0,261-0,534$ \\
\hline
\end{tabular}

\begin{tabular}{cc}
\hline Dimensi Social & $0,476-0,607$ \\
Information Processing & $0,360-0,618$ \\
Dimensi Social Skills & $0,416-0,640$ \\
\hline Dimensi Social Awareness & \\
\hline
\end{tabular}

\section{Skala Resiliensi}

Untuk mendapatkan gambaran mengenai resiliensi yang dimiliki subjek, peneliti menggunakan skala CD-RISC. Alat ukur ini dibuat oleh Connor dan Davidson pada tahun 2003. Skala ini terdiri atas 25 item, yang disusun berdasarkan lima faktor/ dimensi, yaitu (1) Kompetensi personal, standar tinggi, dan kegigihan, (2) Keyakinan terhadap insting, toleransi terhadap efek negatif, dan efek menguatkan dari stress, (3) Penerimaan positif terhadap perubahan dan hubungan lekat dengan orang lain, (4) Kontrol, dan (5) Pengaruh spiritual. Berikut blueprint dari alat ukur CD-RISC:

Tabel 4

Blueprint Skala Resiliensi

\begin{tabular}{ccc}
\hline Faktor yang diukur & Aitem & Contoh Item \\
\hline Kompetensi & 24,12, & Apapun yang terjadi, \\
personal, standar & 11,25, & saya melakukan \\
tinggi, dan & 10,23, & usaha yang terbaik \\
kegigihan & 17,16 & \\
Keyakinan terhadap & 20,18, & Ketika dalam situasi \\
insting, toleransi & 15,6, & yang menekan, saya \\
terhadap efek & 7,19, & mampu tetap fokus \\
negatif, dan efek & 14 & dan berpikir jernih \\
menguatkan dari & & \\
stress & &
\end{tabular}

Penerimaan positif terhadap perubahan

1, 4, 5, Saya dapat dan hubungan lekat dengan orang lain.

2, 8 menghadapi berbagai hal yang terjadi

$\begin{array}{cc}\text { Kontrol } & 23,13, \\ 21 & \begin{array}{c}\text { Saya memiliki } \\ \text { keyakinan yang kuat } \\ \text { dalam mencapai } \\ \text { tujuan }\end{array}\end{array}$

Pengaruh spiritual $\quad 3,9 \quad$ Terkadang saya merasa takdir Tuhan dapat menolong

Jumlah Item 25 item

Skor resiliensi didapatkan dari hasil pengukuran menggunakan skala Likert 
dengan 5 alternatif pilihan jawaban, $\mathrm{STB}=$ Sangat Tidak Benar, HTB $=$ Hampir Tidak Benar, $\mathrm{KKB}=$ Kadang-Kadang Benar, $\mathrm{SB}=$ Seringkali Benar, HSB= Hampir Setiap kali Benar. Skala ini juga tersusun atas 25 item favorable. Skor resiliensi subjek dilihat dari skor total subjek pada skala CD-RISC ini. Semakin tinggi skor total subjek, maka semakin tinggi pula resiliensi yang dimiliki subjek. Begitu pula sebaliknya, semakin rendah skor total subjek, maka semakin rendah pula resiliensinya.

Untuk alat ukur resiliensi ini, peneliti menggunakan skala CD-RISC yang telah diadaptasi sebelumnya oleh Listyandini dan Akmal (2015). Dari proses adaptasi tersebut didapatkan bahwa skala CD-RISC ini valid dan reliabel untuk digunakan. Untuk memastikan reliabilitas alat ukur yang digunakan, peneliti melakukan uji reliabilitas terhadap data yang peneliti gunakan dalam penelitian ini. Berdasarkan hasil uji coba terpakai kepada 177 orang mahasiswa tingkat awal di Jakarta, didapatkan hasil cronbach's alpha sebesar 0,910. Sehingga, dapat disimpulkan bahwa alat ukur ini reliabel, karena memiliki koefisien cronbach's alpha> 0,6. Berikut hasil uji reliabilitas yang telah dilakukan pada tahap uji coba:

Tabel 5

Hasil Uji Reliabilitas CD-RISC

\begin{tabular}{ll}
\hline & Hasil Uji \\
\hline Keseluruhan & 0,910 \\
\hline
\end{tabular}

Berdasarkan uji validitas, didapatkan koefisien korelasi > 0,2 pada semua item, dengan range koefisien item sebesar 0,307 - 0,693. Standar sebuah item dianggap valid dan layak digunakan adalah jika memiliki koefisien korelasi pada nilai corrected item total di atas 0,2 (Nisfiannoor, 2009). Berdasarkan hal tersebut, dapat disimpulkan bahwa semua item dalam alat ukur ini valid digunakan untuk mengukur resiliensi pada mahasiswa. Berikut tabel kesimpulan dari hasil uji validitas tersebut:
Tabel 6

Hasil Uji Validitas CD-RISC

\begin{tabular}{cc}
\hline & Nilai Corrected Item Total \\
\hline Uji Coba & $0,307-0,693$ \\
\hline
\end{tabular}

\section{Teknik Analisis Data}

Teknik analisis statistik yang digunakan dalam penelitian ini adalah uji regresi sederhana dan berganda untuk menguji hipotesis, serta uji beda untuk melihat keterkaitan faktor demografis dengan kedua variabel penelitian.

Sebelum melakukan analisis data, peneliti terlebih dahulu melakukan beberapa uji asumsi data, yaitu uji normalitas dan uji linieritas. Peneliti melakukan uji normalitas menggunakan uji kolmogorov-smirnov yang bertujuan untuk melihat apakah data yang didapat memenuhi distribusi normal atau tidak. Uji normalitas ini peneliti lakukan menggunakan program statistik SPSS for Windows 17.0. Hasil nilai dianggap signifikan jika menunjukkan nilai Sig. > 0,05 (Sujarweni, 2015). Dengan begitu, dapat disimpulkan bahwa data yang diperoleh berdistribusi normal.

Pada tahap selanjutnya peneliti melakukan uji linieritas untuk melihat apakah garis regresi antara X dan Y (kedua variabel) membentuk garis yang linear atau tidak (Sugiyono, 2012). Linieritas sendiri merupakan salah satu asumsi dari analisis regresi. Uji linier yang akan peneliti gunakan adalah uji linear pearson product moment dengan menggunakan SPSS for Windows 17.0. Hasil uji linieritasnya dilihat dari nilai sig. (p) dengan ketentuan yaitu: jika $\mathrm{p}<0,05$, berarti terbentuk hubungan linier antara kedua variabel. Sedangkan apabila data yang didapat tidak mencukupi nilai $\mathrm{p}$-nya dan mendapatkan nilai $\mathrm{p}>0,05$, maka berarti data tersebut tidak membentuk hubungan yang linier (Gani dan Amalia, 2015). Nilai p dilihat dari nilai signifikansi (Sig.) pada hasil perhitungan SPSS.

Setelah melakukan uji asumsi terhadap data penelitian, barulah peneliti melakukan 
uji hipotesis. Analisis yang digunakan dalam penelitian ini adalah analisis regresi; baik analisis regresi linier sederhana maupun regresi ganda. Pengujian hipotesis peneliti lakukan menggunakan aplikasi SPSS for Windows ver. 17.0. Analisis regresi ini bertujuan untuk melihat seberapa jauh perubahan nilai variabel dependen (terikat) jika variabel independen (bebas) dimanipulasi, dengan diubah-ubah atau dinaik-turunkan. Jika koefisien korelasi (r) tinggi, maka pada umumnya koefisien regresi (b) juga tinggi. Sehingga, daya prediksinya juga akan tinggi (Sugiyono, 2010).

Sebagai analisis tambahan, peneliti juga melakukan uji beda terhadap sampel yang bertujuan untuk melihat gambaran distribusi sampel pada variabel kecerdasan sosial, resiliensi, dan karakteristik demografis yang meliputi: usia, jenis kelamin, pengalaman organisasi, mahasiswa rantau/bukan, suku bangsa, dan tingkat pengeluaran.

\section{Hasil Penelitian Dan Pembahasan}

\section{Gambaran Kecerdasan Sosial}

Berikut tabel kategorisasi skor kecerdasan sosial responden:

Tabel 7

Kategorisasi Data Kecerdasan Sosial

\begin{tabular}{cccc}
\hline Kategori & Skor & $\mathrm{N}$ & $\%$ \\
\hline Rendah & $19-57$ & 2 & $1,13 \%$ \\
Sedang & $58-95$ & 113 & $63,84 \%$ \\
Tinggi & $96-133$ & 62 & $35,03 \%$ \\
\hline
\end{tabular}

Berdasarkan tabel, tampak bahwa kecerdasan sosial responden sebagian besar berada pada kategori sedang.

\section{Gambaran Resiliensi}

Berdasarkan hasil kategorisasi terhadap skor resiliensi responden, diperoleh hasil bahwa mayoritas responden memiliki tingkat resiliensi yang tinggi. Berikut tabel kategorisasi skor resiliensi responden:
Tabel 8

Kategorisasi Data Resiliensi

\begin{tabular}{cccc}
\hline Kategori & Skor & $\mathrm{N}$ & $\%$ \\
\hline Rendah & $0-31$ & 1 & $0,56 \%$ \\
Sedang & $32-63$ & 56 & $31,64 \%$ \\
Tinggi & $64-96$ & 120 & $67,80 \%$ \\
\hline
\end{tabular}

Berdasarkan tabel, sebagian besar responden penelitian memiliki resiliensi pada kategori yang tergolong tinggi.

\section{Peran Kecerdasan Sosial terhadap Resiliensi \\ Uji Asumsi Statistik \\ Uji Normalitas}

Sebagai hasil dari uji asumsi data, didapatkan bahwa data pada penelitian ini semuanya berdistribusi normal. Ini dapat diketahui pada semua hasil uji yang memiliki nilai signifikansi atau $\mathrm{p}>0,05$. Seperti yang telah dijelaskan sebelumnya, jika nilai $\mathrm{p}>0,05$ pada hasil uji normalitas data terkait, maka dapat dikatakan data yang diujikan tersebut berdistribusi normal (Sujarweni, 2015).

\section{Uji Korelasi}

Berdasarkan hasil uji korelasi, didapatkan bahwa kecerdasan sosial berhubungan dengan resiliensi secara signifikan $(\mathrm{r}=0.40, \mathrm{p}<0.01)$. Kemudian, berdasarkan hasil uji korelasi tambahan terhadap ketiga dimensi resiliensi, didapatkan bahwa resiliensi berhubungan positif dengan kecerdasan sosial pada dimensi social information processing $(\mathrm{r}=0.40, \mathrm{p}<0.01)$, social skills $(\mathrm{r}=0.32$, $\mathrm{p}<0.01)$ dan social awareness $(\mathrm{r}=0.139$, $\mathrm{p}<0.05)$. Dengan demikian, dapat disimpulkan bahwa kecerdasan sosial secara keseluruhan, maupun ketiga dimensinya berkorelasi secara positif dengan resiliensi. Dengan rentang interval nilai $r=0,1-0,4(p<0,05)$ menunjukkan bahwa adanya hubungan yang positif dengan kekuatan hubungan yang rendah 
hingga sedang antara variabel resiliensi dengan kecerdasan sosial.

\section{Uji Linieritas}

Pada uji linieritas, didapatkan bahwa kecerdasan sosial secara keseluruhan membentuk hubungan yang linier dengan resiliensi. Namun jika dilakukan uji linieritas per dimensi kecerdasan sosial, didapatkan bahwa hanya dimensi social information processing/ kemampuan pengolahan informasi sosial dan dimensi social skills/ keterampilan sosial membentuk hubungan yang linier dengan resiliensi. Sedangkan dimensi social awareness tidak membentuk hubungan yang linier dengan resiliensi.

Setelah melakukan uji asumsi data, peneliti mulai melakukan uji hipotesis.

\section{Uji Hipotesis Penelitian: Regresi Sederhana}

Seperti yang telah dijelaskan sebelumnya, penelitian ini bertujuan untuk mencari seberapa besar peran/ kontribusi variabel kecerdasan sosial terhadap variabel resiliensi pada subjek mahasiswa tingkat awal. Berikut tabel kesimpulan dari hasil uji regresi sederhana yang telah dilakukan:

Tabel 9

Simpulan Uji Regresi Sederhana

\begin{tabular}{ccc}
\hline & $R^{2}$ & $\mathrm{p}$ \\
\hline Kecerdasan Sosial & 0,160 & 0,000 \\
\hline
\end{tabular}

Berdasarkan tabel di atas, didapatkan nilai koefisien determinasi $R^{2}=0,160(\mathrm{p}<$ $.0,01)$. Ini menunjukkan bahwa kecerdasan sosial secara umum memiliki peran yang signifikan terhadap resiliensi pada mahasiswa tingkat awal, dengan kontribusi efektif sebesar $16 \%$, sedangkan sisanya sebesar $84 \%$ dipengaruhi oleh faktor lain.

Peneliti juga melakukan analisis lanjutan berupa pengujian regresi berganda untuk mengetahui kombinasi dimensi mana yang paling berperan terhadap resiliensi pada mahasiswa tingkat awal. Peneliti menguji hipotesis dengan teknik analisis regresi ganda menggunakan program SPSS for Windows 17.0. Peneliti hanya menganalisis dampak dari kombinasi dimensi social information processing dan dimensi social skills dalam kecerdasan sosial terhadap resiliensi. Hal ini peneliti lakukan, karena hasil analisis linieritas sebelumnya menunjukkan bahwa hanya dimensi social information processing dan social skills secara signifikan memiliki hubungan yang linier dengan resiliensi, sedangkan dimensi social awareness tidak memiliki hubungan yang linier secara signifikan dengan resiliensi.

Berdasarkan hasil uji regresi ganda terhadap kedua dimensi tersebut, didapatkan nilai $\mathrm{R}^{2}=0,216 \quad(\mathrm{p}<0.01)$. Berarti, terdapat hubungan yang signifikan antara dimensi social information processing dan dimensi social skills dengan resiliensi pada mahasiswa tingkat awal di Jakarta. Kemudian, koefisien determinasi $R^{2}=0,206 \quad(\mathrm{p}<0,01) \quad$ mengindikasikan bahwa terdapat kontribusi sebesar $20,6 \%$ dari kombinasi dimensi social information processing/ faktor pengolahan informasi sosial dan dimensi social skills/ faktor keterampilan sosial yang berpengaruh terhadap resiliensi, sedangkan sisanya 79,4\% dipengaruhi oleh faktor lain. Berikut adalah tabel kesimpulan dari hasil uji regresi berganda tersebut:

Tabel 10

Simpulan Uji Regresi Berganda

\begin{tabular}{ccc}
\hline & $R^{2}$ & $\mathrm{p}$ \\
\hline $\begin{array}{c}\text { Dimensi Social } \\
\text { Information Processing \& } \\
\text { dimensi Social Skills }\end{array}$ & 0,206 & 0,000 \\
\hline
\end{tabular}

Berdasarkan uji regresi tersebut juga didapatkan konstanta (a) yaitu 34,170 yang menunjukkan bahwa jika tidak ada dimensi social information processing dan dimensi social skills, maka resiliensi mencapai 34,170. Sedangkan nilai $0,748 X 1$ dan 0,365X2 adalah koefisien regresi yang menunjukkan jika setiap penambahan 1 nilai angka untuk dimensi social 
information processing dan dimensi social skills, maka akan ada kenaikan resiliensi sebanyak 0,748 dan 0,365 . Hasil tersebut dapat dilihat pada tabel kesimpulan persamaan hasil uji regresi berganda di bawah ini:

Tabel 11

Persamaan Hasil Uji Regresi Berganda

\begin{tabular}{cc}
\hline & Persamaan Regresi \\
\hline Dimensi Social & $\mathrm{Y}=34,170+0,748 \mathrm{X} 1+$ \\
Information & $0,365 \mathrm{X} 2$ \\
Processing dan & \\
dimensi Social Skills & \\
\hline
\end{tabular}

Keterangan: Y=Resiliensi, X1=Social Information Processing, $\mathrm{X} 2=$ Social Skills

\section{Uji Tambahan: Kaitan Faktor Demografis dengan Resiliensi dan Kecerdasan Sosial}

Berdasarkan hasil uji t-test dan anova, tidak terdapat perbedaan tingkat resiliensi yang signifikan pada ketujuh kelompok responden, yaitu: jenis kelamin, usia, suku bangsa, pengeluaran per bulan, pengalaman organisasi, mahasiswa rantau/tidak rantau, dan asal universitas. Selain itu, peneliti juga melakukan uji korelasi antara usia responden dengan skor dimensi spiritual dalam resiliensi. Berdasarkan hasil uji korelasi tersebut, didapatkan bahwa usia berkorelasi positif dengan dimensi spiritual dalam resiliensi subjek ( $\mathrm{r}=0,014<0,05)$. Berarti, semakin tua usia subjek maka semakin tinggi pula faktor spiritual dalam resiliensi subjek.

Kemudian untuk variabel kecerdasan sosial, berdasarkan hasil uji t-test dan anova tidak terdapat perbedaan tingkat kecerdasan sosial yang signifikan pada ketujuh kelompok responden, yaitu: jenis kelamin, usia, suku bangsa, pengeluaran per bulan, pengalaman organisasi, mahasiswa rantau/tidak rantau, dan asal universitas. Begitu pula dengan masingmasing dimensinya, tidak terdapat perbedaan tingkat kecerdasan sosial pada masing-masing dimensi berdasarkan ketujuh faktor demografis tersebut.

\section{Pembahasan}

Berdasarkan hasil analisis, tampak bahwa kecerdasan sosial secara umum memiliki peran yang signifikan terhadap resiliensi pada mahasiswa tingkat awal, yaitu sebesar $16 \%$, sedangkan sisanya sebesar $84 \%$ dipengaruhi oleh faktor lain. Artinya, mahasiswa tingkat awal yang memiliki kecerdasan sosial yang tinggi akan memiliki resiliensi yang tinggi pula. Hal itu disebabkan karena adanya kecerdasan sosial yang baik dapat membantu mahasiswa tingkat awal bertahan dan mengatasi segala tuntutan serta faktor pemicu stress di sekelilingnya yang menuntut peningkatan kualitas dan kuantitas hubungan sosial. Dengan begitu, mahasiswa tersebut dapat menjadi resilien dalam menjalani perannya sebagai mahasiswa tingkat awal.

Terkait dengan hasil perhitungan regresi pada penelitian ini, peneliti belum dapat menjelaskan faktor lain yang berkontribusi terhadap resiliensi pada mahasiswa tingkat awal. Namun, berdasarkan studi literatur yang telah dilakukan, peneliti menduga bahwa faktor lain yang berkontribusi terhadap resiliensi mahasiswa tingkat awal antara lain: persistensi/ ketekunan, sifat kepemimpinan, bravery/ keberanian dalam menghadapi masalah, sikap openmindedness/ keterbukaan, kemandirian dan tanggung jawab, kemampuan memecahkan masalah, pola asuh, dan peran komunitas terkait dengan permasalahan dalam kehidupan perkuliahan yang dialami responden, seperti masalah akademis dan lain-lain (Listyandini dan Akmal, 2015; Uyun, 2012; Permata, 2015; Landau, 2007).

Dari hasil analisis lanjutan, dapat disimpulkan bahwa dimensi dalam kecerdasan sosial yang paling berkontribusi terhadap resiliensi seorang mahasiswa tingkat awal adalah dimensi social information processing $(0,748)$. Temuan ini dapat dijelaskan dengan melihat keterkaitan antara dimensi social information processing dengan sikap empati. Salah satu 
kemampuan yang menggambarkan dimensi social information processing/ faktor kemampuan pengolahan informasi sosial yang dimiliki individu adalah sikap empati (Dogan dan Cetin, 2009). Penelitian yang dilakukan oleh Rostowsky (dalam Dijkstra, Barelds, Groothof, dan Bruggen, 2014), empati berperan secara signifikan dalam perkembangan dan pemeliharaan hubungan lekat antar individu. Sikap empati dapat membantu individu mengenali tanda-tanda psikologis dan kebutuhan emosi orang lain (Uyun, 2012), yang dapat berperan dalam pembentukan sebuah komunikasi yang efektif antar individu. Kualitas sebuah hubungan ditentukan dari adanya komunikasi yang efektif ini (Sari, Rahim, dan Puluhulawa, 2014). Individu yang memiliki skor dimensi social information processing/ faktor pengolahan informasi sosial yang tinggi juga berarti memiliki kemampuan yang baik dalam memahami pesan-pesan verbal maupun nonverbal dari lingkungannya. Dengan kemampuan tersebut, individu akan tahu apa yang harus ia lakukan dalam situasi sosial dengan membaca pesan-pesan tersebut. Mengetahui apa yang harus dilakukan ini termasuk salah satu kemampuan yang menggambarkan dimensi kontrol dari resiliensi (Connor dan Davidson, 2003). Pada akhirnya, kemampuan ini dapat membantu mahasiswa tersebut dalam membentuk hubungan yang lekat dengan orang lain dan mengontrol kehidupannya sebagai mahasiswa tingkat awal.

Friborg dkk. (2005), menemukan bahwa aspek kompetensi sosial dalam resiliensi berkorelasi positif dengan keterampilan sosial individu. Aryani (2015) juga menemukan bahwa keterampilan sosial yang dimiliki seorang remaja berkontribusi terhadap resiliensi yang dimilikinya. Keterampilan sosial yang meliputi keterampilan-keterampilan dasar dalam berkomunikasi ini merupakan salah satu faktor yang dapat memengaruhi resiliensi, yang terkait dengan kompetensi sosial dan kemampuan interpersonal yang dimiliki individu (Grotberg, dalam Uyun, 2012). Dengan memiliki keterampilan sosial ini, individu tersebut mampu mengungkapkan pikiran dan perasaannya kepada orang lain, serta memahami perasaan dan pendapat orang lain (Uyun, 2012). Dengan memiliki keterampilan tersebut, individu dapat mengembangkan hubungan interpersonal yang lekat dengan orang lain, yang dapat memberikan dukungan sosial dan membantunya untuk dapat menjadi lebih resilien. Mengetahui kepada siapa harus meminta pertolongan ketika menghadapi masalah juga termasuk ke dalam salah satu faktor pembentuk resiliensi, yaitu faktor kontrol (Connor dan Davidson, 2003). Maka dapat disimpulkan, bahwa pada mahasiswa tingkat awal keterampilan komunikasi dapat membantu mereka untuk menjadi lebih resilien dalam menghadapi tuntutan-tuntutan yang muncul terkait dengan peran mereka sebagai mahasiswa tingkat awal, seperti tuntutan akademik dan tuntutan adaptasi.

Dengan kata lain, kemampuan berempati, kemampuan memahami pesanpesan dari lingkungan, dan kemampuan mengungkapkan tujuan dengan cara yang bisa diterima oleh lingkungan dapat memengaruhi kontrol diri dan hubungan lekat mahasiswa, yang secara teoretik merupakan salah satu faktor pembentuk resiliensi. Jika dikaitkan dengan dinamika kehidupan mahasiswa tingkat awal, membentuk hubungan sosial dengan orang lain ini dapat membantu mahasiswa tersebut mengatasi tuntutan tugas perkembangan dan tuntutan akademiknya. Dengan demikian, mahasiswa tersebut dapat lebih resilien dalam mengatasi tugas perkembangan dan tuntutan akademik.

Pada penelitian ini, ditemukan bahwa dimensi social awareness tidak berhubungan secara langsung dengan resiliensi. Hasil tersebut serupa dengan hasil penelitian Condon (2011), yang menemukan bahwa dimensi social awareness/ kesadaran sosial tidak berkorelasi dengan aspek tolerance of 
uncertainty/ toleransi akan ketidakpastian. Aspek tolerance of uncertainty/ toleransi akan ketidakpastian menggambarkan kemampuan seseorang untuk dapat menoleransi situasi yang tidak pasti atau penundaan tanpa merasa cemas atau marah (Bocarnea, Relynolds, dan Baker, 2013). Kemampuan ini senada dengan aspek toleransi terhadap efek negatif dalam resiliensi. Condon (2011), berargumen bahwa tidak adanya korelasi ini disebabkan karena, aspek toleransi akan ketidakpastian tidak dapat dilihat sebagai satu aspek saja, namun harus dilihat sebagai satu kesatuan dengan aspek lain. Berdasarkan hasil uji statistik yang telah dilakukan, peneliti juga berargumen bahwa tidak adanya hubungan yang linier antara dimensi social awareness/ kesadaran sosial dengan resiliensi pada mahasiswa tingkat awal, disebabkan karena berdirinya satu dimensi ini saja tidak dapat menjelaskan hubungan antara kecerdasan sosial dengan resiliensi. Artinya, kemampuan untuk dapat berperilaku sesuai situasi sosial harus diiringi kemunculannya dengan kemunculan kemampuan untuk memahami pesan-pesan di lingkungan dan kemampuan dasar berkomunikasi, agar dapat menjelaskan hubungan antara kecerdasan sosial dan resiliensi pada mahasiswa tingkat awal.

Untuk melihat keterkaitan antara faktor-faktor demografis dengan resiliensi responden, peneliti melakukan uji t-test dan anova. Berdasarkan hasil uji t-test dan anova, tidak terdapat perbedaan tingkat resiliensi yang signifikan pada ketujuh kelompok responden, yaitu: jenis kelamin, usia, suku bangsa, pengeluaran per bulan, pengalaman organisasi, mahasiswa rantau/ tidak rantau, dan asal universitas.

Peneliti juga melakukan uji korelasi antara usia responden dengan skor dimensi spiritual dalam resiliensi. Berdasarkan hasil uji korelasi tersebut, didapatkan bahwa faktor usia responden berkorelasi positif secara signifikan dengan dimensi spiritual dalam resiliensi subjek $(\mathrm{p}=0,023<0,05)$. Berarti, semakin tua usia mahasiswa maka semakin meningkat pula aspek spiritual dalam resiliensinya. Sejalan dengan hasil tersebut, responden yang berusia 19 tahun memiliki skor rata-rata resiliensi yang lebih tinggi daripada responden yang berusia 17 dan 18 tahun, terutama pada dimensi spiritualnya. Spiritualitas dapat didefinisikan sebagai kepercayaan individu akan kuasa Tuhan, dan bahwa segala sesuatu terjadi karena suatu alasan. Ini senada dengan hasil penelitian Jalaludin (2015), yang menemukan bahwa spiritualitas dan perkembangan usia adalah sesuatu yang berjalan beriringan. Semakin meningkat usia seseorang, maka semakin meningkat pula spiritualitas yang dimilikinya. Hal ini disebabkan, semakin matangnya usia dan psikologis individu maka akan semakin meningkat pula kesadarannya untuk meningkatkan spiritualitasnya (Jalaludin, 2015). Dalam penelitian ini, berarti semakin tua usia mahasiswa maka semakin tinggi pula spiritualitas yang dimilikinya.

Selain terhadap resiliensi, peneliti juga melakukan analisis lanjutan terhadap kecerdasan sosial dan tiap dimensinya, berdasarkan faktor-faktor demografis yang secara teoretis memiliki pengaruh terhadap resiliensi dan kecerdasan sosial. Berdasarkan hasil uji $t$-test dan anova, tidak terdapat perbedaan tingkat kecerdasan sosial yang signifikan pada ketujuh kelompok responden, yaitu: jenis kelamin, usia, suku bangsa, pengeluaran per bulan, pengalaman organisasi, mahasiswa rantau/ tidak rantau, dan asal universitas. Begitu pula dengan masing-masing dimensinya, tidak terdapat perbedaan tingkat kecerdasan sosial pada masing-masing dimensi berdasarkan ketujuh faktor demografis tersebut. Hasil yang sama juga ditemukan dalam penelitian yang dilakukan oleh Sarvamangala (2012). Dalam penelitiannya, tidak ditemukan korelasi yang signifikan antara faktor sosiodemografis seperti jenis kelamin, usia, kasta/ golongan masyarakat, dan status perkawinan dengan kecerdasan sosial.

Faktor demografi berupa pengalaman berorganisasi juga ditemukan tidak ber- 
korelasi dengan kecerdasan sosial, baik secara keseluruhan maupun per dimensinya. Hasil ini bertolak belakang dengan hasil penelitian yang dilakukan oleh Umbara dkk. (2012), yang menemukan bahwa pengalaman berorganisasi dapat meningkatkan keterampilan sosial mahasiswa. Ini disebabkan oleh perbedaan karakteristik dari subjek penelitian Umbara dkk. (2012), yang mana penelitian tersebut secara spesifik hanya mengambil subjek mahasiswa yang memiliki pengalaman organisasi selama masa perkuliahan selama satu tahun. Pada penelitian ini peneliti tidak mempertimbangkan waktu dan pengalaman organisasi yang dimiliki oleh responden. Lalu mengingat bahwa responden dalam penelitian ini merupakan mahasiswa tingkat awal, pengalaman organisasi yang mereka miliki bukanlah saat berada di tingkat perkuliahan. Oleh karena itu, pengalaman organisasi tersebut tidak dapat menjelaskan kemunculan kecerdasan sosial responden.

\section{Simpulan dan Saran}

Simpulan

Hasil analisis menunjukkan bahwa kecerdasan sosial berkontribusi sebesar $16 \%$ terhadap resiliensi pada mahasiswa tingkat awal, sedangkan $84 \%$ lainnya diduga dipengaruhi oleh faktor lain. Ditemukan bahwa kecerdasan sosial secara keseluruhan berperan terhadap resiliensi pada mahasiswa tingkat awal.

Hasil analisis lanjutan juga menunjukkan bahwa dimensi social information processing yang menggambarkan kemampuan memahami pesan-pesan yang ada di lingkungan, dan dimensi social skills yang menggambarkan kemampuan-kemampuan dasar berkomunikasi merupakan aspek yang terbukti paling berkontribusi secara signifikan terhadap resiliensi.

\section{Saran}

Beberapa saran yang dapat digunakan sebagai bahan pertimbangan untuk perbaikan penelitian, yaitu;
Penelitian selanjutnya terkait kecerdasan sosial, disarankan untuk dapat menggali faktor-faktor apa saja yang belum tergali dalam penelitian ini yang dapat memengaruhi kecerdasan sosial responden. Contohnya, seperti perbe-daan program studi dan sistem pem-belajaran selama masa perkuliahan.

Penelitian selanjutnya mengenai resiliensi mahasiswa, disarankan untuk dapat menggali faktor-faktor selain kecerdasan sosial yang dapat berkontribusi terhadap resiliensi responden. Contohnya seperti peran komunitas untuk masalah akademik atau komunitas mahasiswa rantau.

Penelitian selanjutnya disarankan untuk lebih memperhatikan variasi dan jumlah responden saat proses adaptasi dan uji coba alat ukur agar dapat menghindari terjadinya penghapusan item.

Penelitian selanjutnya, peneliti menyarankan untuk dapat lebih mengontrol keseimbangan persebaran jumlah responden terkait faktor demografisnya seperti jurusan, jenis kelamin, tipe sekolah, dan lain-lain, agar didapat hasil penelitian yang lebih ideal, tanpa adanya error akibat persebaran responden yang kurang merata.

Penelitian selanjutnya, disarankan untuk menggali alasan mengapa mayoritas responden memiliki tingkat resiliensi dan kemampuan memahami pesan-pesan di lingkungan sosial yang tinggi. Peneliti menduga, hal ini dapat disebabkan oleh asal jurusan/ program studi. Oleh karena itu, untuk penelitian selanjutnya mengenai kecerdasan sosial dan resiliensi, peneliti menya-rankan untuk dapat mengontrol program studi responden sebagai faktor demografis.

Berdasarkan hasil penelitian yang telah dilakukan, terdapat beberapa implikasi praktis dari penelitian ini, yaitu;

Untuk membantu meningkatkan resiliensi pada diri sendiri, seorang mahasiswa tingkat awal harus meningkatkan kemampuannya untuk memahami lingkungan di sekitarnya dan 
keterampilan-keterampilan

dasar berkomunikasi yang dimilikinya. Kemampuan individu untuk mema-hami lingkungan di sekitar dan keterampilanketerampilan dasar ber-komunikasi yang menggambarkan dimensi social information processing dan dimensi social skills terbukti berperan terhadap resiliensi pada mahasiswa tingkat awal.

Untuk membantu meningkatkan resiliensi pada mahasiswa tingkat awal, pihak pemegang kebijakan pendidikan dapat mengeluarkan kebijakan terkait pendidikan yang dapat mengasah kecerdasan sosial mahasiswanya, sehingga dapat mem-bantu mereka untuk menjadi lebih resilien. Contohnya dengan pengadaan program support group untuk mahasiswa oleh Dosen Pembimbing Akademik, pengadaan mata kuliah bimbingan pendidikan, dan mempertimbangkan pembentukan Student Advisory Council untuk mengembangkan fungsi-fungsi kecer-dasan sosial para mahasiswa

\section{Daftar Pustaka}

Amelia, S., Asni, E., \& Chairilsyah, D. (2014). Gambaran Ketangguhan Diri (Resiliensi) pada Mahasiswa Tahun Pertama Fakultas Kedokteran Universitas Riau, Jurnal Online Mahasiswa Bidang Kedokteran, 1(2), 1-9.

Aryani, E. (2015). Korelasi antara Keterampilan Sosial dengan Resiliensi pada Siswa Kelas XII SMK Negeri 1 Salam Pasca Bencana Lahar Dingin Merapi, Skripsi, Yogyakarta: Fakultas Ilmu Pendidikan Universitas Negeri Yogyakarta.

Bennett, B. (2015). Social Intelligence of Undergraduates Enrolled in Traditional vs. Distance Higher Education Learning Programs, Disertasi, Minnesota: Walden University.

Bhana, A. \& Bachoo, S. (2011). The Determinants of Family Resilience among Families in Low- and MiddleIncome Context: A Systematic Literature Review, South African Journal of Psychology, 41(2), 131-139. Bocarnea, M.C., Reynolds, R.A., \& Baker, J.D. (2013). Online Instruments, Data Collection, and Electronic Measurements: Organizational Advancement, Amerika Serikat: Information Science Reference.

Brougham, R.R., Zail, C.M., Mendoza, C.M., \& Miller, J.R. (2009). Stress, Sex Differences, and Coping Strategies among College Students, Curr Psychol, 28, 85-97. Springer Science Bussiness Media, LLC. DOI 10.1007/s12144-009-9047-0.

Clark, M.R. (2005). Negotiating the Freshmen Year: Challenges and Strategies among First-year College Students, Journal of College Student Development, 46(3), 296-316.

Condon, R.J. (2011). The Relationship between Self-awareness and Leadership: Extending Measurement and Conceptualisation, Disertasi, Canterbury: Universitas Canterbury.

Connor, K.M., \& Davidson, J.R.T. (2003). Development of a New Resilience Scale: The Connor-Davidson Resilience Scale (CD-RISC), Depression and Anxiety, 18, 76-82.

Dijkstra, P., Barelds, D.P.H., Groothof, H.A.K., \& Bruggen, M.V. (2014). Empathy in Intimate Relationships: The Role of Positive Illusions, Scandinavian Journal of Psychology, 55, 477-482.

Dogan \& Cetin. (2009). The Validity, Reliability, and Factorial Structure of the Turkish Version of the Tromso Social Intelligence Scale, Educational Sciences: Theory \& Practice, 9(2), 709-720.

Everall, R.D., Altrows, K.J., \& Paulson, B.L. (2006). Creating a Future: A Study of Resilience in Suicidal Female Adolescents, Journal of Counseling \& Development, 84, 461-470. 
Fan, S., Pandya-Lorch, R., \& Yosef, S. (Ed.). (2014). Resilience for Food and Nutrition Security, Washington D.C.: International Food Policy Research Institute.

Frankovsky, M. \& Birknerova, Z. (2014). Measuring Social Intelligence-The MESI Methodology, Asian Social Science, 10(6), 90.

Friborg, O., Barlaug, D., Martinussen, M., Rosenvinge, J.H., \& Hjemdal, O. (2005). Resilience in Relation to Personality and Intelligence, International Journal of Methods in Psychiatric Research, 14(1), 29-42.

Gani, I. \& Amalia, S. (2015). Alat Analisis Data: Aplikasi Statistik untuk Penelitian Bidang Ekonomi dan Sosial, Yogyakarta: ANDI.

Hernandez, N.E. (2007). The Mental Health of College Students: Challenges, Obstacles, and Solutions, The Millenial Student: A National Symposium.

https://www.nyu.edu/frn/publications/ millennial.student/Mental-HealthHernandez.html.

Hutapea, E. (2006). Gambaran Resiliensi pada Mahasiswa Perantau Tahun Pertama Perguruan Tinggi di Asrama UI (Menggunakan Resilience Scale), Skripsi, Depok: Fakultas Psikologi UI.

Jalaludin. (2015). Tingkat Usia dan Perkembangan Spiritualitas serta Faktor yang Melatarbelakanginya di Majelis Tamasya Rohani Riyadhul Jannah Palembang, Intizar, 21(2).

Karp, M.M. (2007). Learning about the Role of College Student through Dual Enrollment Participation, CCRC Working Paper No: 7, New York: Columbia University.

Landau, J. (2007). Enhancing Resilience: Families and Communities as Agents for Change, Family Process, 46(3), 351-367. Doi: 10.1111/j. 15455300.2007.00216x.

Linley, P.A. \& Joseph, S. (2004). Positive Change following Trauma and
Adversity: A Review, Journal of Traumatic Stress, 17(1), 11-21.

Listyandini, R.A. \& Akmal, S.A. (2015). Hubungan antara Kekuatan Karakter dan Resiliensi pada Mahasiswa, Prosiding Temu Ilmiah Nasional Psikologi, Jakarta: Fakultas Psikologi Universitas Pancasila.

Nisfiannoor, M. (2009). Pendekatan Statistika Modern untuk Ilmu Sosial, Jakarta: Salemba Humanika.

Permata, D.C. (2015). Peranan Pola Asuh Orang Tua terhadap Resiliensi Mahasiswa Tahun Pertama yang Merantau di Jakarta serta Tinjauannya dalam Islam, Skripsi, Jakarta: Universitas YARSI.

Reivich, K. \& Shatte, A. (2002). The Resilience Factors, New York: Broadway Books.

Rinaldi. (2010). Resiliensi pada Masyarakat Kota Padang Ditinjau dari Jenis Kelamin, Skripsi, Padang: Fakultas Ilmu Pendidikan Universitas Negeri Padang.

Rosiana, D. (2011). Penyesuaian Akademis Mahasiswa Tingkat Pertama, Skripsi, Bandung: Universitas Islam Bandung.

Ross, S.E., Niebling, B.C., \& Heckert, T.M. (1999). Source of Stress among College Students, College Student Journal, 33(2), 312-317.

Rozali, Y.A. (2015). Kecerdasan Interpersonal Remaja Ditinjau dari Penerapan Pola Asuh Orang Tua, Seminar Psikologi \& Kemanusiaan, 446-452. Psychology Forum UMM.

Sari, N., Rahim, M., \& Puluhulawa, M. (2014). Korelasi antara Sikap Terbuka dengan Komunikasi Interpersonal Siswa Kelas VIII SMP Negeri 2 Limbotu Barat Kabupaten Gorontalo, Skripsi, Prodi S1 Bimbingan dan Konseling, Periode September 2014, 2(3).

Sarvamangala, D.R. (2012). A Study of Socio-demographic Factors on Social Intelligence among Secondary School 
Teachers, International Journal of Scientific Research, 1(5).

Silvera, D.H., Martinussen, M., \& Dahl, T.I. (2001). The Tromso Social Intelligence Scale, a Self Report Measure of Social Intelligence, Scandinavian Journal of Psychology, 42, 313-319.

Soejanto, L.T. \& Soekarman, F.I. (2015). Tingkat Kecerdasan Sosial Mahasiswa Fakultas Keguruan dan Ilmu Pendidikan Universitas Kanjuruhan Malang, Jurnal Konseling Indonesia, 1(1), 18-28.

Sokol, J.T. (2009). Identity Development throughout the Lifetime: An Examination of Eriksonian Theory, Graduate Journal of Counseling Psychology, 1(2), Article: 14. http://epublications.marquette.edu/gjcp /vol1/iss2/14.

Sonn, C.S. \& Fisher, A.T. (1998). Sense of Community: Community Resilient Responses to Oppression and Change, Journal of Community Psychology, 26(5), 457-472. CCC 00904392/98/050457-16.

Strage, A. \& Brandt, T.S. (1999). Authoritative Parenting and College Students' Academic Adjustment and Success, Journal of Educational Psychology, 91(1), 146.

Sugiyono. (2010). Metode Penelitian Kuantitatif Kualitatif dan $R \& D$, Bandung: Alfabeta.

(2012). Statistika untuk Penelitian, Bandung: Alfabeta.

Sujarweni, V.W. (2015). SPSS untuk Penelitian, Yogyakarta: Pustaka Baru Press.

Sunjoyo, R.S., Carolina, V., Magdalena, N., \& Kurniawan, A. (2013). Aplikasi SPSS untuk Smart Riset (Program IBM SPSS 21.0), Bandung: Penerbit Alfabeta.

Umbara, H.T.K., Lilik, S., \& Agustin, R.N. (2012). Hubungan antara Kematangan Emosi dan Penerimaan Diri dengan
Keterampilan Sosial pada Mahasiswa Organisatoris, Wacana, 4(7).

Ursin, H. \& Eriksen, H.R. (2010). Cognitive Activation Theory of Stress (CATS), Neuroscience \& Biobehavioral Review, 34, 877-881. http://dx.doi.org/10.1016/j.neubiorev.2 009.03.001

(2004). The

Cognitive Activation Theory of Stress, Psychoneuroendocrinology, 29, 567592. http://dx.doi.org/10.1016/S03064530(03)00091-X

Uyun, Z. (2012). Resiliensi dalam Pendidikan Karakter, Prosiding Seminar Nasional Psikologi Islami, Surakarta: Universitas Muhammadiyah Surakarta.

Vancu, E. (2014). Social Competence, Emotional Intelligence in Adolescents within a Stress-resilience Model, The 2nd Human and Social Sciences at the Common Conference, 128-130. http://www/hassacc.com/

Verger, P., Combes, J.B., Kovess-Masfety, V., Choquet, M., Guagliardo, V., Rouillon, F., \& Peretti-Wattel, P. (2009). Psychological Distress in First Year University Students: Socioeconomic and Academic Stressors, Mastery, and Social Support in Young Men and Women, Social Psychiatry and Psychiatric Epidemiology, 44(8), 643-650.

Wicaksono, G. \& Naqiyah, N. (2013). Penerapan Teknik Bermain Peran dalam Bimbingan Kelompok untuk Meningkatkan Kemampuan Komunikasi Interpersonal Siswa Kelas X Multimedia SMK IKIP Surabaya, Journal Mahasiswa Bimbingan Konseling, 1(1), 61-78.

Widuri, E.L. (2012). Regulasi Emosi dan Resiliensi pada Mahasiswa Tahun Pertama, Humanitas, IX(2), 148-156.

\section{Sumber Internet dan Majalah}

Albrecht, K. (2014). https://www. karlalbrecht.com. Social Intelligence 
Theory. (Diakses secara online pada 5 November 2015).

http://www.smu.edu/Provost/ALEC/NeatSt uffforNewStudents/HowIsCollegeDiffe rentfromHighSchool. How is College Different from High School. (Diakses secara online pada 5 November 2015).

http://www.uad.ac.id. Mengembangkan Kecerdasan Sosial. (Diakses secara online pada 11 Maret 2016).

Kementerian Pendidikan dan Kebudayaan. (2013). Diakses dari www.kemdikbud.go.id 
Psympathic, Jurnal Ilmiah Psikologi Juni 2017, Vol. 4, No.1, Hal: 67 - 90 